\title{
Religiosity and corporate risk-taking: evidence from Italy
}

\author{
Richard J. Cebula ${ }^{1} \cdot$ Fabrizio Rossi ${ }^{2}$ \\ Accepted: 8 February 2021/Published online: 13 March 2021 \\ (c) Academy of Economics and Finance 2021
}

\begin{abstract}
This study investigates the impact of local culture, as measured by religiosity, on corporate risk-taking, based on a sample of 155 Italian listed firms, involving 2,382 firm-year observations over the study period 2000-2016. The empirical estimation results suggest a statistically significant negative relationship between corporate risk-taking and religiosity, i.e., greater religiosity reduces corporate risk-taking behavior. Overall, these results are consistent with the empirical literature dealing with other nations on the relationship between corporate decisions and social values (local culture). Finally, the findings are robust to alternative empirical specifications.
\end{abstract}

Keywords Corporate risk-taking $\cdot$ Social values $\cdot$ Religion $\cdot$ Culture

JEL Classification $\mathrm{G} 32 \cdot \mathrm{G} 41 \cdot \mathrm{A} 13 \cdot \mathrm{Z} 12$

\section{Introduction}

Recently, some studies have emphasized the role that social values, local culture, and religious beliefs play in explaining economic growth, corporate decisions, and organizational behavior, including agency costs, dividend policy, and corporate risk-taking (e.g., Chintrakarn et al. 2017; Diez-Esteban et al. 2019). Guiso et al. (2006, p. 23) define culture "... as those customary beliefs and values that ethnic, religious, and social groups transmit fairly unchanged from generation to generation." La Porta et al. (1999) find that, beyond the institutional factors, there are other cultural factors, such as religiosity, that can influence corporate

Richard J. Cebula

rcebula@gmu.edu; dr.richardcebula@gmail.com

Fabrizio Rossi

f.rossi@unicas.it

1 Department of Economics and Center for the Study of Public Choice, George Mason University, 4400 University Dr, Fairfax, VA 22303, USA

2 Department of Electrical and Information Engineering, University of Cassino and Southern Lazio, Via G. Di Biasio 43, 03043 Cassino, FR, Italy 
behavior. McGuire et al. (2012) find that religiosity can discourage managers from engaging in unethical business practices. Du (2013) and Chintrakarn et al. (2017) find that religious piety substitutes effectively for corporate governance in alleviating the agency problem. Furthermore, Diez-Esteban et al. (2019) find that religiosity has an impact on corporate risk-taking.

Using a sample of 155 public firms based in Italy, for 2,382 firm-year observations, over the period 2000-2016, this empirical study investigates for the case of Italy the relationship between corporate risk-taking and local culture, as measured by religiosity. The study contributes to the existing literature in two ways.

First, Italy has a history of being a locus of people with strong religious beliefs and arguably thereby provides us to test a "natural environment" for investigating the potential impact of religiosity on corporate risk taking. Indeed, the population of Italy has been especially strongly associated with the Catholic religion and its highest authorities as represented by the Papacy for the Roman Catholic Church. Catholic Social Teaching (CST) takes the position that a firm is a "common good" and has the right to earn a profit. Nevertheless, the owners must manage the firm using ethical behavior. Catholic Social Teaching (CST) recognizes the firm's goal to profit on real investments based on the right risk without highly speculative financial activities. Therefore, religiosity actually could have a strong impact on corporate risk-taking behavior in Italy. We analyze data from ISTAT (The National Institute for Statistics) on the percentage of the population aged 6 years or older that attended a formal religious congregation at least once a week over the previous 12 months in the region where the firms' headquarters are located. On average, data indicate that approximately $30 \%$ of the Italian population attend such religious congregations. Therefore, we hypothesize that Italian firms' religious beliefs are likely to affect firms' organizational behavior and be an essential factor in explaining an aversion to extensive corporate risk-taking.

Second, this study examines a single bank-based French Civil Law country that offers less overall shareholder protection and fewer creditor rights (La Porta et al. 1999) than typically provided in Common Law countries. Italian companies have a higher ownership concentration than typically found in other countries, and it is in theory potentially easier for the largest shareholder(s) to extract private benefits of control from the minority stockholders. Indeed, several previous empirical studies find that agency costs are more severe for Italian firms and that the probability of expropriation of wealth to the detriment of minority shareholders, through firms' debt levels, pyramidal groups, dividend policies, and dual-class shares, is higher than other countries (e.g., Faccio et al. 2010; Dyck and Zingales 2004). Previous empirical studies also find that religious piety substitutes effectively for corporate governance in alleviating agency issues in countries other than Italy (Chintrakarn et al. 2017).

While a growing body of literature has investigated the relationship between religiosity and risk-taking in US and other countries, to our best knowledge few studies have examined civil law countries and no study has investigated Italy. Therefore, the goal of our paper is to measure if there is a relationship between religiosity and corporate risk-taking in Italian listed firms. Following other 
studies (e.g., Harjoto and Rossi 2019; Rossi et al. 2019), we hypothesize that firms located in more religious areas exhibit lower levels of risk-taking.

This study consists of four more Sections. Section 2 discusses related literature and develops the hypotheses, while Section 3 describes the data sample and survey methodology. Section 4 provides the empirical results and a discussion of the findings, whereas Section 5 provides a brief summary of the estimation findings and the conclusions of this study.

\section{Literature review and hypothesis development}

There is a widely held belief that corporate culture affects corporate value. For example, Guiso et al. (2015) find that managerial integrity and managerial ethics affect firm value, although corporate governance seemingly does not influence corporate culture.

Literature in the field of psychology suggests that, on average, a more religious person is more risk-averse (Miller and Hoffmann 1995; Diaz 2000; Miller 2000; Bartke and Schwarze 2008; Liu 2010; Noussair et al. 2013; Cebula 2014; León and Pfeifer 2017). Some studies find that a higher degree of religiousness/religiosity can influence firms' policies and lower firms' risk-taking behavior (e.g., Callen and Fang 2015). Hilary and Hui (2009) find that firms located in counties with higher levels of religiosity display lower degrees of risk exposure, as measured by variances in equity returns or returns on assets. Such firms also exhibit a lower investment rate and less growth, but generate a more positive market reaction when they announce new investments. Chen et al. (2016) find that a greater degree of religiosity, i.e., stronger religious convictions regarding morality, play a more significant role in constraining opportunistic behavior towards minority stockholders; furthermore, this is found to be especially true in legal environment that are less protective of stockholder rights. Kanagaretnam et al. (2015) find that banks located in more religious countries exhibited lower levels of risk in their decision-making and were less likely to encounter financial difficulty or to fail during the 2007-2009 financial crisis.

Adhikari and Agrawal (2016) find that US banks headquartered in areas that are more religious exhibit lower risks and are less vulnerable to crises, since they tend to grow slower, hold safer assets, are less involved in non-traditional banking businesses, and provide less option compensation to their executives. Blau (2017) finds that religious adherence and religious beliefs lower the volatility of stock prices in Catholic counties in the US.

Renneboog and Spaenjers (2012) find that Catholics attach great importance to thrift and tend to be risk-averse. Protestants combine a more external locus of control with a greater sense of financial responsibility. León and Pfeifer (2017) find that different religious affiliations are associated with distinct financial risk-taking attitudes. Adherents to the two main Christian religions in Germany (Protestants and Catholics) have been found to be less risk-tolerant than the population as a whole. In another study (Diez-Esteban et al. 2019), it was found that that different religious backgrounds tend to have different impacts on corporate risk-taking. These impacts were found to be negative for predominantly Catholic and Islamic-based countries and positive for firms in 
predominantly Protestant nations. Also, Gharbi et al. (2020) find that higher degrees of religiosity can reduce the financial distress. Specifically, they document that corporates headquarters situated in more religious U.S. counties are probably less to suffer from financial problems and that the negative relationship is becomes stronger during the financial crisis.

Very few studies have investigated the potential relationship between religion and corporate risk-taking in single based French Civil Law countries such as Italy. Accordingly, this study hypothesizes that, ceteris paribus, given its impact on overall corporate behavior, greater religiosity reduces the degree of corporate risk-taking in Italy. In particular, this study examines a sample of Italian listed companies. It is recognized that the population in Italy has on average strong Catholic religious beliefs. A survey of Italian families has recently confirmed that Italian investors are largely risk-averse and prefer to hold low-risk investments in their portfolios. Furthermore, a high aversion to losses and a low-risk appetite remain quite common characteristics among Italian savers (Consob 2017). In other words, Italian investors are receptive to a (low) risk type of investment (Avvenire October 30, 2017).

The Catholic religion advocates that one should invest in socially responsible investments that protect against risk, reflecting ethical and honest behavior. Moreover, the Catholic religion advocates that one reduce the risk of conflict with stakeholders (Pope Francis, "Oeconomicae et pecuniariae quaestiones" May 17 2018). Catholic Social Teaching (CST) recognizes as legitimate the firm's goal to profit on investments based on a modest level of risk without engaging in significant speculative financial activities. Most of the Encyclicals written during several papacies, as well as De Rerum Novarum by Pope Leo XIII in 1891, The Centesimus Annus (CA) issued by Pope John Paul II, the encyclical Caritas in Veritate by Pope Benedict XVI and recent writings by Pope Francis, including Evangelii Gaudium and Laudato Si, are based on these very same principles. Catholic Social Teaching also suggests acting ethically and protecting the stakeholder's interest because the firm is regarded as a "common good" whose goals include earning reasonable profits and creating employment and wealth for the local community. Since corporate risk-taking is associated with unethical practices (KishGephart et al. 2010) that, in turn, increase the expropriation of wealth to the detriment of minority shareholders, we hypothesize that the local culture (as proxied by greater religiosity) diminishes preferences for risk-taking by Italian companies and that firms headquartered in more religious areas within Italy tend to take less risk than firms located in less religious areas.

Based on the above discussion, our fundamental hypothesis is, as follows:

Hypothesis 1 (H1): Listed firms in Italy that have headquarters located in areas characterized by higher religiosity undertake less risk-taking behavior

\section{Methodology and data analysis}

Similarly to previous studies on religiosity and corporate decisions for Italian listed firms (e.g., Harjoto and Rossi 2019; Rossi et al. 2019) we build a sample of 155 non-financial and non-regulated companies that are listed continuously on the Italian 
stock market during the period 2000-2016, which provides 2,382 firm-year observations. At the end of 2016, there were 244 listed companies on the Mercato Telematico Azionario. We exclude 44 financial firms, 14 utilities, and 31companies because data are unavailable or the companies were suspended. We also exclude all new entry firms (IPOs) not listed continuously for at least five years over the period to 2016. Our final sample includes 155 firms, which enables us to build an unbalanced panel dataset that includes all non-financial and non-regulated Italian-listed companies whose individual time-series range from a minimum of 8 years to a maximum of 17 years. We also build our sample based on data that includes firm-specific characteristics (e.g., SIZE, AGE, ROA, LEVERAGE, PAYOUT, ANALYSTS and CASH).

The following OLS (Ordinary least square) describes the baseline specification:

$$
y_{i, t}=\mu_{i, t}+\alpha_{1} \text { RELIGIOSITY }_{i, t}+\alpha_{2} \text { CONTROL_VARIABLES }_{i, t}+\eta_{t}+\varepsilon_{i, t}
$$

where $y_{i, t}$ is the value of the dependent variable $(R \& D$ - Research and Development, $\left.C A S H \_F L O W, S T \_D E V I A T I O N\right)$ for firm $i$ in year $t$.

However, instead of using $R \& D$ and $C A S H \_F L O W$ per se, we calculate the residuals of these two variables using the methodology of Biddle et al. (2009). Biddle et al. (2009) use the residuals as a firm-specific proxy for deviations from expected investment and then include the residuals estimated in the regression as dependent variables. Specifically, we run the first stage regression using the following equation:

$$
\text { Investment }_{i, t+1}=\beta_{0}+\beta_{1} * \text { SalesGrowth }_{i, t}+\varepsilon_{i, t+1}
$$

where the dependent variable Investment ${ }_{i, t+1}$ indicates, alternatively, $R \& D$ and CASH_FLOW, while the independent variable SalesGrowt ${ }_{i, t}$ is measured as the annual change in revenue.

Using this methodology, we can construct two measures of excess risk-taking, namely, EX_R\&D and EX_CASH. The CONTROL_VARIABLES include a set of firm-specific characteristics, SIZE, AGE, ROA, LEVERAGE, PAYOUT, ANALYSTS and $C A S H$ (see Table 1 for precise definitions of the variables in the model). We also include INDUSTRY as measured by the four-digit SIC codes (excluding all SIC codes 6000-6999 and 4900-4999) using a set of dummy variables that measure nine different industries; $\eta_{t}$ is the temporal dummy; $\varepsilon$ is the residual term and $t=2000,2001,2002 \ldots 2016$. Except for variables in logarithmic form, all variables with values higher than the mean plus-or-minus three standard deviations are considered outliers and winsorized to the 5th and 95th percentiles. This study collected data from ISTAT, Bloomberg, COMPUSTAT, FactSet, and Calepino dell'Azionista.

Both the dependent and independent variables have been chosen following the previous literature on risk-taking and agency costs (Jensen and Meckling 1976; Jensen 1986; John et al. 2008; Chintrakarn et al. 2017; Diez-Esteban et al. 2019; Hilary and Hui 2009; Harjoto and Rossi 2019; Rossi et al. 2019). Consistent with previous studies, we also use an instrumental variable approach (IV) to account for endogeneity and the possibility of reverse causality (e.g., Hilary and Hui 2009; Chintrakarn et al. 2017, 2018; Adhikari and Agrawal 2016; Rossi et al. 2019). In particular, we use an indicator variable, namely $L O G \_C H U R C H E S$, as 


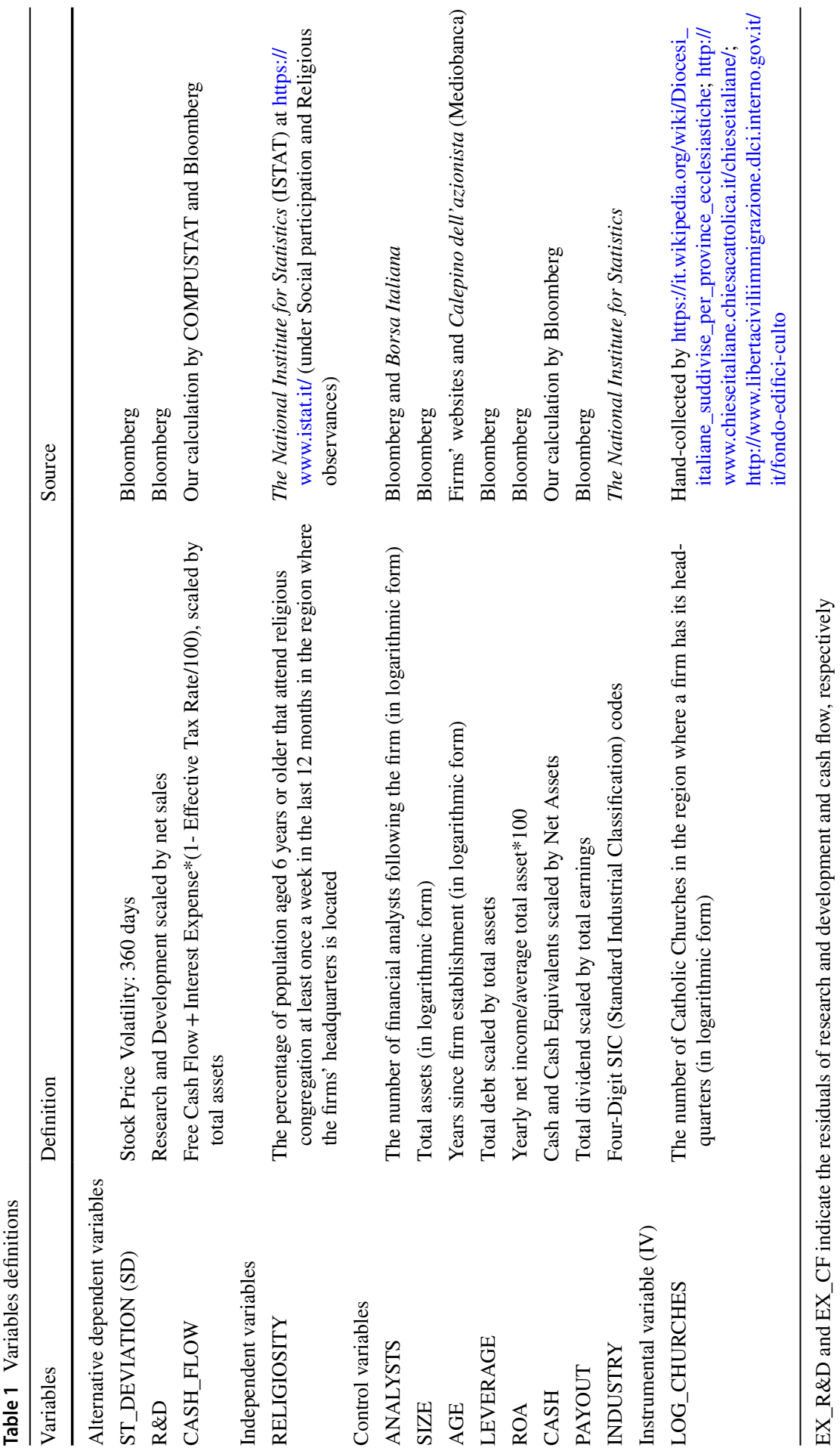


our instrumental variable. Although it is not easy to find a correct instrumental variable, we believe that the number of Catholic Churches is an acceptable instrument because it is correlated with RELIGIOSITY but not with our dependent variables (Greene 2012). We also use the number of Catholic Churches in logarithmic form ( $\left.L O G \_C H U R C H E S\right)$ to take into account that in some regions the number of Catholic Churches is much higher than in other regions. For instance, the number of Catholic Churches ranges from 591 in Umbria to 3,527 in Triveneto. To construct this variable we manually collect the number of Catholic Churches for each region where a firm has its headquarters using several sources (see Table 1). In unreported results, we also use the number of Catholic Churches scaled by the population of the region where a firm has its headquarters as an instrumental variable, but the empirical results remain unchanged.

Tables 1 and 2 contain the descriptions and the descriptive statistics for all of the variables. We find a RELIGIOSITY rate of $29.5 \%$, with a median equal to $30.7 \%$; these values are higher than found by Hilary and Hui (2009) for the U.S. We also find, on average, that R\&D, ROA and CASH are $0.49 \%, 0.9 \%$ and $11.3 \%$, respectively. The mean firm age is 37 years and the mean of total assets is $2,890.197$ (in thousands $€$ ). On average, the 155 firms have a debt-to-total asset ratio equal to $26.9 \%$, with a standard deviation of $33.5 \%$. The public firms in Italy tend to hold more cash and incur less debt but also are less profitable and smaller than the public firms in the U.S. (Hilary and Hui 2009; Chintrakarn et al. 2017).

Table 2 Descriptive statistics

\begin{tabular}{lccc}
\hline Variables & Average & Median & \multicolumn{1}{l}{ S.D } \\
\hline Alternative dependent variables & & & \\
R\&D & 0.496 & 0.000 & 1.346 \\
ST_DEVIATION (SD) & 0.335 & 0.337 & 0.165 \\
CASH_FLOW & -0.002 & 0.011 & 0.073 \\
Independent variables & & & \\
$\quad$ RELIGIOSITY & 0.295 & 0.307 & 0.060 \\
Control variables & & & \\
PAYOUT & 0.229 & 0.000 & 0.305 \\
SIZE (thousand euros) & $2,890.197$ & 326,23 & $1,813,00$ \\
SIZE (in logarithmic form) & 2.596 & 2.513 & 0.768 \\
FIRMAGE (in years) & 37.00 & 26.00 & 31.73 \\
AGE (in logarithmic form) & 1.412 & 1.415 & 0.383 \\
LEVERAGE & 0.269 & 0.274 & 0.159 \\
ANALYSTS & 0.413 & 0.301 & 0.443 \\
ROA & 0.009 & 0.016 & 0.062 \\
CASH & 0.113 & 0.075 & 0.106 \\
INDUSTRY & YES & & \\
Number of observations & 2,382 & & \\
\hline
\end{tabular}

EX_R\&D and EX_CF indicate the residuals of research and development and cash flow, respectively 


\section{Empirical findings and discussion}

The estimation results are provided in Table 3. In Column 1, we find that our instrumental variable is positively and significantly correlated with RELIGIOS$I T Y$, the key explanatory variable upon which this study principally focuses. We also find that, except for the variables SIZE, AGE, ANALYSTS, and PAYOUT, the remaining variables are not statistically significant.

In Column 2, we find that the coefficient on the dependent variable RELIGIOS$I T Y$ is negative and statistically significant at the 1 percent level, implying that $E X \_R \& D$, which is our first measure of risk-taking behavior, is a decreasing function of RELIGIOSITY, as hypothesized (in H1). For the interested reader, it is also observed that the coefficients on the control variables $C A S H, R O A, A G E$, ANALYSTS, and PAYOUT are all statistically significant and positive, implying that all of these factors may increase risk-taking.

Thus, those firms that operate in more religious areas tend/are inclined to avoid excessive risk-taking. This result supports the idea that more religious firms adopt more ethical behaviors towards the shareholders by not investing stakeholders' interest. The results also show that firms that have more cash, that are older [i.e., are more established], that have greater profitability, and that make higher dividend payouts experience greater risk-taking behavior. At the same time, we also find that the number of financial analysts following the firm fails to effectively control unethical behaviors. In addition, although the coefficient on LEVERAGE is negative, it is not statistically significant. In any case, unlike the agency theory framework, the framework of stronger religious belief seems to curb firms' opportunistic behavior better than the traditional tools identified by Jensen and Meckling (1976).

Previous research (e.g., Chintrakarn et al. 2018) suggests that variable for religiosity, RELIGIOSITY, could suffer from endogeneity problems. We use the residuals from the first stage of our regression (Column 1), namely, the INSTR_RELIGIOS$I T Y$ variable, to check whether the results are driven by endogeneity. In Column 3 of Table 3, we find that results are extremely similar to those in Column 2, even when we thusly check for endogeneity. Based on the estimation results in Columns 4 and 5 of Table 3, we find that $E X \_C F$ is negatively and significantly related to both RELIGIOSITY and INSTR_RELIGIOSITY. In addition, firms that have headquarters in more religious areas hold less excessive cash flows and thereby take less risk. We also find that coefficients on variables LEVERAGE, PAYOUT, and ANALYSTS are all negative and statistically significant, implying negative impacts on excessive risktaking behavior, whereas the positive and significant coefficients for the variables for profitability and the size of firms imply elevated excessive risk-taking behavior.

Furthermore, based on the findings shown in Columns 6 and 7, $S D$ is a decreasing function of RELIGIOSITY and INSTR_RELIGIOSITY, implying that firms whose headquarters are located in regions/areas with more pronounced religious beliefs experience less price volatility in the equity market. The coefficients for SIZE, ROA, and PAYOUT are all negatively significant, implying less share price volatility, whereas the share price for firms that have more debt, that have more financial analysts following, and that are older are less stable/more volatile in the stock market. 
Table 3 Empirical estimates using the residuals of R\&D and cash flow and standard deviation of stock price as alternative dependent variables*

\begin{tabular}{|c|c|c|c|c|c|c|c|}
\hline & $\begin{array}{l}\text { First stage } \\
\text { (1) }\end{array}$ & $\begin{array}{l}\text { EX_R\&D } \\
\text { (2) }\end{array}$ & $\begin{array}{l}\text { EX_R\&D } \\
\text { (3) }\end{array}$ & $\begin{array}{l}\text { EX_CF } \\
\text { (4) }\end{array}$ & $\begin{array}{l}\text { EX_CF } \\
(5)\end{array}$ & $\begin{array}{l}\text { SD } \\
(6)\end{array}$ & $\begin{array}{l}\text { SD } \\
\text { (7) }\end{array}$ \\
\hline Constant & $\begin{array}{l}0.2024 * * * \\
(0.0299)\end{array}$ & $\begin{array}{l}-0.5008^{* * *} \\
(0.1881)\end{array}$ & $\begin{array}{l}-0.9302 * * * \\
(0.1422)\end{array}$ & $\begin{array}{l}0.0049 \\
(0.0097)\end{array}$ & $\begin{array}{l}-0.0101 \\
(0.0083)\end{array}$ & $\begin{array}{l}0.3269 * * * \\
(0.0246)\end{array}$ & $\begin{array}{l}0.2974 * * * \\
(0.0196)\end{array}$ \\
\hline LEVERAGE & $\begin{array}{l}-0.0021 \\
(0.0090)\end{array}$ & $\begin{array}{l}-0.0093 \\
(0.1708)\end{array}$ & $\begin{array}{l}0.0135 \\
(0.1713)\end{array}$ & $\begin{array}{l}-0.0321^{* * *} \\
(0.0099)\end{array}$ & $\begin{array}{l}-0.0313 * * * \\
(0.0100)\end{array}$ & $\begin{array}{l}0.0864 * * * \\
(0.0235)\end{array}$ & $\begin{array}{l}0.0884 * * * \\
(0.0235)\end{array}$ \\
\hline $\mathrm{CASH}$ & $\begin{array}{l}0.0008 \\
(0.0120)\end{array}$ & $\begin{array}{l}0.9298 * * * \\
(0.2877)\end{array}$ & $\begin{array}{l}0.9007 * * * \\
(0.2905)\end{array}$ & $\begin{array}{l}-0.0497 * * * \\
(0.0118)\end{array}$ & $\begin{array}{l}-0.0508^{* * * *} \\
(0.0119)\end{array}$ & $\begin{array}{l}0.0042 \\
(0.0353)\end{array}$ & $\begin{array}{l}-0.0019 \\
(0.0350)\end{array}$ \\
\hline SIZE & $\begin{array}{l}0.0062^{* * * *} \\
(0.0019)\end{array}$ & $\begin{array}{l}0.0351 \\
(0.0529)\end{array}$ & $\begin{array}{l}0.0201 \\
(0.0536)\end{array}$ & $\begin{array}{l}0.0121^{* * * *} \\
(0.0027)\end{array}$ & $\begin{array}{l}0.0116^{* * *} \\
(0.0023)\end{array}$ & $\begin{array}{l}-0.0572 * * * \\
(0.0064)\end{array}$ & $\begin{array}{l}-0.0585^{* * *} \\
(0.0063)\end{array}$ \\
\hline$R O A$ & $\begin{array}{l}-0.0003 \\
(0.0024)\end{array}$ & $\begin{array}{l}0.0152 * * * \\
(0.0048)\end{array}$ & $\begin{array}{l}0.0165^{* * *} \\
(0.0049)\end{array}$ & $\begin{array}{l}0.0083^{* * *} \\
(0.0002)\end{array}$ & $\begin{array}{l}0.0084^{* * *} \\
(0.0002)\end{array}$ & $\begin{array}{l}-0.0079 * * * \\
(0.0006)\end{array}$ & $\begin{array}{l}-0.0077 * * * \\
(0.0006)\end{array}$ \\
\hline$A G E$ & $\begin{array}{l}-0.0250^{* * *} \\
(0.0024)\end{array}$ & $\begin{array}{l}0.3843 * * * \\
(0.0617)\end{array}$ & $\begin{array}{l}0.3800^{* * *} \\
(0.0624)\end{array}$ & $\begin{array}{l}-0.0014 \\
(0.0036)\end{array}$ & $\begin{array}{l}-0.0015 \\
(0.0036)\end{array}$ & $\begin{array}{l}0.1014 * * * \\
(0.0089)\end{array}$ & $\begin{array}{l}0.0954 * * * \\
(0.0089)\end{array}$ \\
\hline ANALYSTS & $\begin{array}{l}-0.0072 * * \\
(0.0035)\end{array}$ & $\begin{array}{l}0.4471 * * * \\
(0.0882)\end{array}$ & $\begin{array}{l}0.4576^{* * * *} \\
(0.0892)\end{array}$ & $\begin{array}{l}-0.0022 * * * \\
(0.0035)\end{array}$ & $\begin{array}{l}-0.0212 * * * \\
(0.0035)\end{array}$ & $\begin{array}{l}0.1065 * * * \\
(0.0108)\end{array}$ & $\begin{array}{l}0.1073 * * * \\
(0.0108)\end{array}$ \\
\hline PAYOUT & $\begin{array}{l}0.0105 * * \\
(0.0047)\end{array}$ & $\begin{array}{l}0.3483^{* * *} \\
(0.0900)\end{array}$ & $\begin{array}{l}0.3455^{* * *} \\
(0.0900)\end{array}$ & $\begin{array}{l}-0.0074 * * \\
(0.0036)\end{array}$ & $\begin{array}{l}-0.0076^{* *} \\
(0.0036)\end{array}$ & $\begin{array}{l}-0.0002 * * \\
(0.0001)\end{array}$ & $\begin{array}{l}-0.0214 * * \\
(0.0100)\end{array}$ \\
\hline $\begin{array}{l}\text {LOG}_{-} \\
\quad C H U R C H E S\end{array}$ & $\begin{array}{l}0.3137 * * * \\
(0.0997)\end{array}$ & & & & & & \\
\hline RELIGIOSITY & & $\begin{array}{l}-0.0158 * * * \\
(0.0042)\end{array}$ & & $\begin{array}{l}-0.0005^{* * *} \\
(0.0002)\end{array}$ & & $\begin{array}{l}-0.0013^{* *} \\
(0.0005)\end{array}$ & \\
\hline $\begin{array}{l}\text { INSTR_RELIGI- } \\
\quad \text { OSITY }\end{array}$ & & & $\begin{array}{l}-0.0155^{* * *} \\
(0.4306)\end{array}$ & & $\begin{array}{l}-0.0005^{* *} \\
(0.0002)\end{array}$ & & $\begin{array}{l}-0.3039 * * * \\
(0.0576)\end{array}$ \\
\hline INDUSTRY & YES & YES & YES & YES & YES & YES & YES \\
\hline$Y E A R$ & YES & YES & YES & YES & YES & YES & YES \\
\hline$R$-squared & 0.085 & 0.087 & 0.085 & 0.474 & 0.473 & 0.225 & 0.231 \\
\hline Adj. R-squared & 0.074 & 0.074 & 0.072 & 0.466 & 0.466 & 0.215 & 0.221 \\
\hline F-Value & $21.67 * * *$ & $25.83 * * *$ & $25.30 * * *$ & $68.57 * * *$ & $68.29 * * *$ & $46.57 * * *$ & $51.31 * * *$ \\
\hline N. Obs & 2,382 & 2,382 & 2,382 & 2,382 & 2,382 & 2,382 & 2,382 \\
\hline
\end{tabular}

*The dependent variables EX_R\&D and EX_CF indicate the residuals of research and development and cash flow, respectively. Estimated values have been calculate using the model of Biddle et al. (2009). INSTR_RELIGIOSITY has been calculated as the residual of the first stage of regression (Column 1). *** and ** indicate statistical significance at the 1 percent and 5 percent levels, respectively

Overall, the estimation results support our hypothesis $(H 1)$ that firms located in more highly religious areas experience/engage in less risk-taking. They seem to adopt more ethical behavior in terms of the stakeholders' interests. The results also suggest that religiosity, as a manifestation of cultural and social value, has a strong impact on corporate behavior, as argued by previous studies (La Porta et al. 1999; Guiso et al. 2006; Hilary and Hui 2009; Guiso et al. 2015; Chintrakarn et al. 2018; Diez-Esteban et al. 2019). 
Moreover, it is observed that our results remain robust in several alternative specification estimations. In additional estimations, we adopt Generalized Method of Moment (GMM) two-step and Fixed-effect models using both the residuals (EX_R\&D and EX_CF) of Biddle et al. (2009), and the traditional variables $R \& D$ and $C A S H-F L O W$, but the conclusions are unchanged.

\subsection{Robustness check}

Since our time horizon of analysis includes the period of economic and financial crisis and our results could potentially be driven by omitted variable bias, we also run an additional test. Specifically, we include in our regressions two additional variables, namely CRISIS and CRISIS*INSTR_RELIGIOSITY, to measure the moderating effects. If our results were driven by the crisis period, we would expect that the coefficient on INSTR_RELIGIOSITY to lose strength and that the CRISIS *INSTR_RELIGIOSITY coefficient to exhibit a negative and statistically significant sign. Again, in un-reported results, we find that coefficient INSTR_RELIGI$O S I T Y$ keeps its negative and statistically significant coefficient while the coefficient of CRISIS*INSTR_RELIGIOSITY exhibits a not statistically significant value when the dependent variables are $E X \_R \& D$ and $E X \_C F$ and a positive and statistically significant coefficient when the dependent variable is $S D$. Therefore, we can reject the conclusion that the results are driven by the crisis period. To the contrary, the results emerge strengthened and demonstrate more compellingly that religiosity discourages excess risk-taking practices.

We also include the percentage of shares held by larger shareholders as an additional control variable, but again the basic conclusions remain unchanged. Finally, it is also observed that the maximum value of VIFs (variance inflation factors) in the model is only 2.8 , so that we can reasonably conclude that multicollinearity is not an issue in our analysis.

\section{Conclusions}

Historically, Italy has been strongly associated with the Catholic religion and the highest authorities in the Papacy for the Roman Catholic Church. Catholic Social Teaching (CST) points out that a firm is a "common good" and has the right to earn a profit, but in the interest of stakeholders, the owners must manage the firm using ethical behavior. Since religiosity as a cultural and social value has been linked to several behavioral traits, among others, honesty, risk aversion, good corporate governance, and ethical behaviors, we investigate the relationship between corporate risk-taking and religiosity. The analysis adopts a sample of 155 Italian listed companies during the period 2000-2016. Our results strongly support the idea that greater religiosity decreases corporate excess risk-taking and unethical behaviors by firms. From the agency theory perspective, religiosity can be a useful tool to control and monitor agency costs; moreover, this conclusion is obtained even when we include the most significant shareholders as an additional variable in our specification. 
To our best knowledge, this study is the first that analyses the relationship between religiosity and corporate risk-taking in Italy. Previous studies suggest that Catholic religiosity dampen unethical behavior of firms. Harjoto and Rossi (2019) find that higher rate of religiosity increase the ethics rating of Italian listed firms. Rossi et al. (2019) find a positive relationship between religiosity and dividend payouts, with firms headquartered in higher religiosity areas paying more dividends than firms located in lower religiosity areas. Their results also suggest that religiosity of Italian firms could mitigate agency costs and that are consistent with the "bird in the hand" view as compared to the "two birds in the bush" view. Renneboog and Spaenjers (2012) find that Catholics attach more importance to thrift and are more risk-averse. Montenegro (2017), using a sample of Portuguese firms, finds a positive relationship between religiosity and financial reporting quality. Her results suggest that religiosity, together with other forms of external monitoring, represents a mechanism for reducing overly aggressive accounting practices.

Based also on previous findings, we believe that our results can be extended to countries with high catholic religiosity and lower investors protection (e.g., Spain, France and Portugal). Furthermore, our results provide valuable insights to academicians, corporate managers, investors, and regulators regarding the role of religiosity and social values as determinants in the decision-making process.

Anyway, our study, as other studies, suffer of some limitations. First, we do not consider the financial firms (e.g., banks) that have been involved in several unethical behaviors in the last years. Secondly, even if we use a fixed effects model, as an additional model, and we find unchanged results, we do not include in our analyses the corporate governance indicators.

Future research in this area could extend the role of religiosity and his impact on bankruptcy, financial irregularities, earnings management, for Italian listed firms and other Catholic religious countries. Furthermore, future research could also investigate the relationship between religiosity and corporate risk-taking using other risk proxies, as well as the z-score and standard deviation of return on assets. We also believe that all unresolved issues around the relationship between religiosity and corporate risk-taking could be examined using the crisis post Covid-19 as an exogenous shock.

\section{References}

Adhikari BK, Agrawal A (2016) Does local religiosity matter for bank risk-taking? J Corp Finan 38:272-293. https://doi.org/10.1016/j.jcorpfin.2016.01.009

Avvenire Resta alta la sfiducia su tutela degli investimenti (October 30, 2017), available at: http:// www.repubblica.it/economia/affari-e-finanza/2017/12/11/news/il_risparmio_gestito_supera_i_ bot-people_ma_agli_italiani_il_rischio_non_piace-183742867/

Bartke S, Schwarze R (2008) Risk-averse by nation or by religion?: some insights on the determinants of individual risk attitudes (No. 131). DIW Berlin, The German Socio-Economic Panel (SOEP)

Biddle GC, Hilary G, Verdi RS (2009) How does financial reporting quality relate to investment efficiency? J Account Econ 48(2-3):112-131

Blau BM (2017) Religiosity and the volatility of stock prices: a cross-country analysis. J Bus Ethics 144(3):609-621. https://doi.org/10.1007/s10551-015-2842-7

Callen JL, Fang X (2015) Religion and stock price crash risk. J Finan Quant Anal 50(1-2):169-195 
Cebula RJ (2014) The impact of economic freedom and personal freedom on net in-migration in the U.S.: a state-level empirical analysis, 2000 to 2010. J Labor Res 35:88-103

Chen H, He Huang H, Lobo GJ, Wang C (2016) Religiosity and the cost of debt. J Bank Finance 70:70-85. https://doi.org/10.1016/j.jbankfin.2016.06.005

Chintrakarn P, Jiraporn P, Tong S, Chatjuthamar P (2017) Exploring the effect of religious piety on corporate governance: Evidence from anti-takeover defenses and historical religious identification. J Bus Ethics 141:469-476

Chintrakarn P, Chatjuthamard P, Jiraporn P, Kim YS (2018) Exploring the causal effect of religious piety on dividend policy: evidence from historical religious identification. Appl Econ Lett 26:1-5

Consob (2017) Report 2017 on financial investments of Italian households. Available at: http://www. consob.it/web/consob-and-its-activities/rf2017

Diaz JD (2000) Religion and gambling in sin-city: a statistical analysis of the relationship between religion and gambling patterns in Las Vegas residents. Soc Sci J 37(3):453-458

Diez-Esteban JM, Farinha JB, Garcia-Gomez CD (2019) Are religion and culture relevant for corporate risk-taking? International evidence. Bus Res Q 22(1):36-55

Du X (2013) Does religion matter to owner-manager agency costs? Evidence from China. J Bus Ethics 118(2):319-347

Dyck A, Zingales L (2004) Private benefits of control: an international comparison. J Finan 59(2):537-600

Faccio M, Lang LH, Young L (2010) Pyramiding vs leverage in corporate groups: international evidence. J Int Bus Stud 41(1):88-104

Gharbi I, Hamed-Sidhom M, Hussainey K, Ganouati J (2020) Religiosity and financial distress in U.S. firms. Int J Finan Econ. https://doi.org/10.1002/ijfe.1994

Greene W (2012) Econometric analysis, 7th edn. Pearson, New York

Guiso L, Sapienza P, Zingales L (2006) Does culture affect economic outcomes? J Econ Perspect 20(2):23-48

Guiso L, Sapienza P, Zingales L (2015) The value of corporate culture. J Financ Econ 117:60-76

Harjoto MA, Rossi F (2019) Religiosity, female directors and corporate social responsibility for Italian listed companies. J Bus Res 95:338-346

Hilary G, Hui KW (2009) Does religion matter in corporate decision making in America? J Financ Econ 93(3):455-473

Jensen MC (1986) Agency costs of free cash flow, corporate finance and takeovers. Am Econ Rev 76(2):323-329

Jensen MC, Meckling WH (1976) Theory of the firm: managerial behavior, agency costs, and ownership structure. J Financ Econ 3(4):305-360

John K, Litov LP, Yeung BY (2008) Corporate governance and risk taking. J Finan 63(4):1679-1728

Kanagaretnam K, Lobo GJ, Wang C, Whalen DJ (2015) Religiosity and risk-taking in international banking. J Behav Exp Finan 7:42-59

Kish-Gephart JJ, Harrison DA, Treviño LK (2010) Bad apples, bad cases, and bad barrels: metaanalytic evidence about sources of unethical decisions at work. J Appl Psychol 95(4):1-31

La Porta R, Lopez-de-Silanes F, Shleifer A, Vishny R (1999) The quality of government. J Law Econ Organ 15(1):222-279

León AK, Pfeifer C (2017) Religious activity, risk-taking preferences and financial behaviour: empirical evidence from German survey data. J Behav Exp Econ 69(1):99-107

Liu EY (2010) Are risk-taking persons less religious? Risk preference, religious affiliation, and religious participation in Taiwan. J Sci Study Relig 49(1):172-178

McGuire ST, Omer TC, Sharp NY (2012) The impact of religion on financial reporting irregularities. Account Rev 87(2):645-673

Miller AS (2000) Going to hell in Asia: the relationship between risk and religion in a cross cultural setting. Rev Relig Res 42(1):5-18

Miller AS, Hoffmann JP (1995) Risk and religion: an explanation of gender differences in religiosity. J Sci Study Relig 34(1):63-75

Montenegro TM (2017) Religiosity and corporate financial reporting: evidence from a European country. J Manag Spiritual Relig 14(1):48-80. https://doi.org/10.1080/14766086.2016.1249395

Noussair CN, Trautmann ST, Van de Kuilen G, Vellekoop N (2013) Risk aversion and religion. J Risk Uncertaint 47(2):165-183

Pope Francis “'Oeconomicae et pecuniariae quaestiones', (May 17, 2018). available at: https://press.vatic an.va/content/salastampa/it/bollettino/pubblico/2018/05/17/0360/00773.html 
Renneboog L, Spaenjers C (2012) Religion, economic attitudes, and household finance. Oxf Econ Pap 64(1):103-127

Rossi F, Barth J, Sun Y (2019) Does religiosity affect the dividend payouts of Italian-listed companies? J Manag Spiritual Relig 16(4):348-371. https://doi.org/10.1080/14766086.2019.1618605

Publisher's note Springer Nature remains neutral with regard to jurisdictional claims in published maps and institutional affiliations. 